\title{
Integration of fashion design education with innovation and entrepreneurship education
}

\begin{abstract}
The paper proposes a systematic education framework combining fashion major with innovation and entrepreneurship in higher education, in terms of target and position, curriculum system, teaching methods, practical platform, quality evaluation, teaching staff, and teaching materials. An empirical study was conducted using BIF (Business + Internet+Fashion) method to verify the framework. Thus, a solution is provided to the gap of convergence between fashion education and innovation and entrepreneurship education.
\end{abstract}

Keywords: fashion design, innovation and entrepreneurship, higher education, fashion business, pedagogy
Volume 6 Issue 3 - 2020

\author{
Li Zeng \\ School of Art and Design, Shenzhen Polytechnic, China
}

Correspondence: Li Zeng, Associate Professor, School of Art and Design, Shenzhen Polytechnic, Liuxian Blvd., Nanshan District, Shenzhen, Guangdong, China, Email zengli99@szpt.edu.cn

Received: May 05, 2020 | Published: May 22, 2020

\section{Introduction}

China government released an "Innovation and Entrepreneurship" policy in 2015. At the same year, a relevant policy approached to higher education and deepened the educational reform, which targeted to build an educational system of Innovation and Entrepreneurship in higher education in 2020. These measures have been viewed or illustrated as incentives of economy growth and alternative solutions to employment, especially expanding students in higher education in recent decade.

Fashion design is a multi-discipline filed integrating aesthetics and technology. Its materialized products are highly commercial and fashionable, are closely related to daily life of the public, and have a broad and solid market foundation. Entrepreneurship is to grow markets and create employment. ${ }^{1}$ Innovation and entrepreneurship of fashion has obvious advantage over other products and industries, with small initial investment, a low threshold and low-risk, thus is easy to star up. Clothing design micro and small businesses require little startup capital and are some of the more feasible business. ${ }^{2}$ Fashion is suitable for innovation and entrepreneurship. The proliferation of fashion design studios and freelancers confirms this phenomenon. In the process of innovation and entrepreneurship, fashion design professionals feature strong practical ability, challenge to innovate, and are good at creative thinking. They give full play of artistic accomplishment and fashion design skills, make the best of strengths and avoid weaknesses from both aesthetic and practical perspectives, so as to avoid the model of innovation and entrepreneurship which requires strong business skills.

The connotation of fashion major focuses on design and application, and emphasizes on students' hands-on practice and creative ability. Its convergence with innovation and entrepreneurship is based on professional and industry. The quo education system of innovation and entrepreneurship in fashion major is under development. ${ }^{3}$ It is at a stage of individual and part-time study, with insufficient resources, lacking of qualified entrepreneurial tutor, and with a narrow audience. A state-of-the-art integration of innovation and entrepreneurship education and fashion major will form an overall systematic engineering, combine the spirit of innovation and entrepreneurship into the construction of fashion curriculum system, and reform talent training model, teaching practice, teaching staffs of fashion, teaching materials and other aspects. Building a comprehensive education system integrating fashion and innovation and entrepreneurship will reflect the characteristics of higher education, fashion design and innovation and entrepreneurship, achieve balance and unity of professional development and innovation and entrepreneurship.

This paper inserts into a research gap where few studies address fashion design entrepreneurship as a field, this topics is approached to contribute to the scientific exploration of fashion design and entrepreneurial activity in the field. ${ }^{3}$ It proposes a systematic framework which contributes to the solution of innovation and entrepreneurship education in fashion major, and implies an opportunity to incorporate innovation and entrepreneurship with fashion education. This systemic integration brings together several pivotal components into one system.

\section{Methods}

\section{Objective and positioning of innovation and entrepreneurship education in fashion major}

The framework should adhere to the value orientation of the organic integration of fashion major and innovation and entrepreneurship, so as to found a solid base of innovation and entrepreneurship education in fashion major. The framework will embody the effective combination of vocational skills training of fashion and ability improvement of innovation and entrepreneurship, e.g. combination of innovation and entrepreneurship and professional, professional and market, art and technology, theory and practice. It aims at developing fashion courses based on innovation and entrepreneurship, a clear structure of curriculum and innovative content system. Other objectives involve unique and diversified teaching models, advanced teaching methods, scientific assessment and evaluation. Furthermore, the framework will target building practical platforms, excellent teaching staffs, advanced teaching materials. The whole system is technically fashion education focusing on cultivation of innovation and entrepreneurship, processes and tasks of innovation and entrepreneurship in fashion will be analyzed and generalized into three basic capabilities, namely professional ability, social capability and method capability. Learning tasks and fields of innovation and entrepreneurship are concluded based on fashion courses, which curriculum system, pedagogical approaches, practical platforms, evaluation system, teaching staffs and teaching materials serve for. The construction process of education system is shown in Figure 1. 


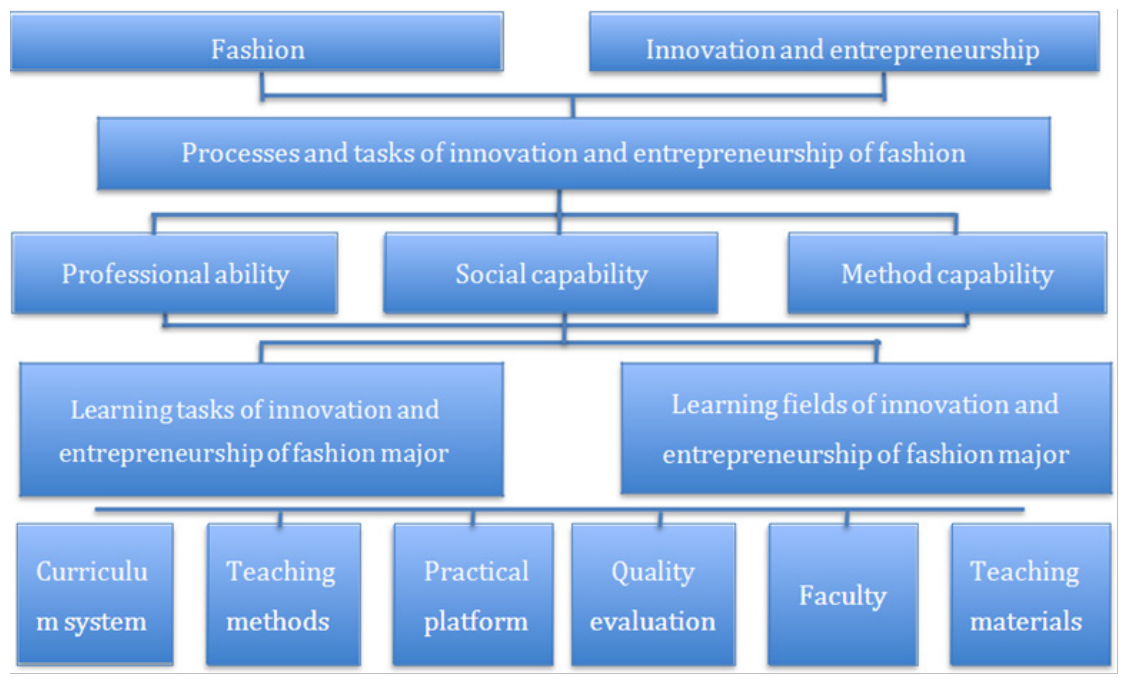

Figure I Education system integrating fashion major and innovation and entrepreneurship.

Curricula system of fashion major combing with innovation and entrepreneurship education

Developing the curriculum system of fashion major fusing innovation and entrepreneurship education is the core of the integration of the two. The rationality of curriculum and the effectiveness of implementation are the crux to realizing teaching objectives. The curriculum system focuses closely on the goal of innovation and entrepreneurship education, fully explores the connotation of innovation and entrepreneurship in professional courses, and combines with knowledge transfer, skill training and the improvement of innovative and entrepreneurial capabilities.

When integrating fashion major and innovation and entrepreneurship education, it is vital and necessary to study the processes and tasks of innovation and entrepreneurship in fashion, analyze the required professional ability, social capability and method ability, which then are transferred into corresponding learning fields and learning tasks of fashion major, so as to build a curriculum system oriented by innovation and entrepreneurship.

Firstly, curriculum system based on innovation and entrepreneurship requires in-depth and comprehensive research on entrepreneurial characteristics, business model and operation of fashion companies, especially small and micro enterprises, design studios and independent designers with successful entrepreneurial experience, as well as students. The awareness and identification of relevant business building blocks provide a starting point. ${ }^{4}$ Processes and tasks of innovation and entrepreneurship of fashion are summarized and analyzed, the responsibilities of each process are determined which then are subdivided into specific small tasks with strong execution, including demand introduction, team building, project planning, target user analysis, competitive product analysis, brainstorm, sketch storm, sketch refinement, design plan, material plan, pattern design, sampling, mass production, marketing, business model, cost accounting, profit plan, etc.

Through the description of small tasks, the required capabilities and qualities of innovation and entrepreneurship, including professional capabilities, methodological capabilities and social capabilities, are classified, decoded and synthesized. "The education of designers should not be exclusively about know-how, focusing on technical abilities, technologies and methodologies that are not sufficient on their own, but should focus on knowledge, knowing how to be, how to interact and communicate, with the dominance of skills related to leadership and coordination in teams, with innovation and creativity, skills that are more directed to their insertion and adaptation in the corporate ground" ${ }^{5}$ Common professional abilities include art design, aesthetics, market analysis and planning, financial management etc. Social capabilities include handling social networks, communication and coordination, leadership, teamwork, etc. Method capabilities include self-study, observation and thinking, analysis and problem solving, effective control etc. Among them, professional ability is hard ability, social competence and method ability are soft ability based on innovation and entrepreneurship. Special emphasis is placed on practice ability of design innovation, application ability of innovation achievement, product launching ability, marketing ability, financial management ability and risk management ability. Innovation and entrepreneurship should also involve the psychological qualities of determination to explore, the willingness to take risks, and the tolerance of risks and failure.

According to the required abilities, these processes and tasks of innovation and entrepreneurship in fashion are decomposed and adjusted into learning fields and tasks which are suitable for teaching, such as product design, outsourcing processing, follow-up orders, cost accounting and business model etc. Then through teachers' teaching analysis and integration, these learning fields and tasks are logically synchronized with professional actions of innovation and entrepreneurship, which reveals curriculum characteristics of a nonsingle discipline system.

The new curricula of fashion are finally readapted for innovation and entrepreneurship. It can be observed from the above analysis that knowledge structure and ability of innovation and entrepreneurship have been greatly adjusted on the basis of fashion major. For students majoring in fashion, innovation and creativity are not difficult. The gap between fashion education and entrepreneurship education is that conceptual innovation and design idea cultivated in fashion courses only stay at the stage of design schemes or samples, without market launching. In order to develop students' market awareness and entrepreneurial ability, management knowledge and skills must be introduced substantially. On the basis of curriculum design 
of fashion major, it is necessary to add "marketing", "financial management", "e-commerce", "human resource management", "common knowledge of business and tax regulations" and other business management courses. Entrepreneurship courses should be formally and systematically studied, in order to understand market demand and market trends, accurately position creative products, and handle operation and management of enterprises. Relevant courses can refer to 15 compulsory courses on entrepreneurship knowledge in Babson College in US, covering finance, management, marketing consulting, growth, risk and other fields1. 17 professional courses at Stanford Graduate School of Business not only include necessary entrepreneurial knowledge, but also other higher-level entrepreneurial knowledge, such as selection and evaluation of entrepreneurship opportunities, development strategy, technology innovation etc.

The ratio of fashion major courses and management major courses, compulsory courses and elective courses, on-campus courses and intern courses is appropriately planned in order to develop the innovation and entrepreneurship as the core. In short, the curriculum system of innovation and entrepreneurship must follow the principle of "knowledge, ability and quality", covering the training of entrepreneurial awareness, the training of entrepreneurship ability, the guidance of entrepreneurial methods and other teaching contents.

\section{Practical platform of innovation and entrepreneurship} education of fashion education

Statistics show that nearly half of the students have had thought about starting a business, but failed to move into the stage of plan and implementation. The main reasons involve lack of a good entrepreneurial atmosphere and the inability to provide open entrepreneurship centers and platforms in campus. Having entrepreneurial passion and entrepreneurial knowledge does not mean that all challenges in the entrepreneurial process can be overcome. It is difficult to develop entrepreneurial risk awareness, risk aversion ability, psychological tolerance, willpower and other qualities in classroom. Indeed, they are cultivated through practical projects.

Following the trend of diversified methods of training, in addition to courses, the practical platform of innovation and entrepreneurship either inside or outside the campus, as continuation of curriculum and graduation design projects, may exert experience of actual projects, enlighten and cultivate students' innovative thinking and entrepreneurial awareness, and arise students' enthusiasm to actively participate in innovation and entrepreneurship. It also urges students to develop many practical skills and gain rich practical experiences, to be familiar with entrepreneurial policies and related legal knowledge, to exercise a keen sense of the market, to target to solve practical problems of innovation and entrepreneurship, and to avoid some risks of entrepreneurial failure. Various types of students' selforganized communities of entrepreneurship allow students interested in entrepreneurship to find like-minded organizations of innovation and entrepreneurship, to stimulate the passion of innovation and entrepreneurship. In fashion studios, teachers with strong practical experiences, industry masters or part-time teachers from enterprises serve as mentors of innovation and entrepreneurship to conduct entrepreneurial projects and team counseling. It is also propose that universities unite governments, introduce enterprises, build integrated industrial chain of government, industry, education and research, promote the platform construction including innovation and entrepreneurship bases, university entrepreneurship parks and incubators, establish entrepreneurship scholarship, and focus on training and supporting students and graduates with the potential of innovation and entrepreneurship, finally realize industrialization of innovation and entrepreneurship achievements. Using the system of students' application for entrepreneurial projects and enterprise experts' evaluation, innovation and entrepreneurship projects can obtain preferential supports such as IP, venues, funds, daily operating equipment, administrative processes, public secretaries and project consulting after projects are settled down. Online integration platform of original design works and independent designers is especially suitable for fashion students to explore innovation and entrepreneurship, which serves as an intermediary that directly connects the needs of enterprises and students' innovative design achievements. Platform of innovation and entrepreneurship is progressively hierarchical, involving student club, department studio, university entrepreneurial park and university-enterprise incubator. These online and offline multi-level and multi-directional platforms give full play to the positive role of the service, guidance and operability, and improve the coverage of innovation and entrepreneurship education.

\section{Evaluation system of innovation and entrepreneurship education of fashion major}

Objective and accurate evaluation of implementation and achievement of innovation and entrepreneurship courses is an effective guarantee to achieve the goal of innovation and entrepreneurship education. Guided by the evaluation of the ability of innovative thinking and entrepreneurship, based on positioning of course function and requirement of course goal, a "knowledge, skills and quality" three-in-one evaluation system is established. Thus knowledge evaluation and capability evaluation, process evaluation and final evaluation are integrated organically into teaching process, multi-perspective, multi-form, multi-method, multi-stage and multicategory comprehensive evaluation methods of innovation and entrepreneurship are formed. In order to cultivate students' innovative spirit and entrepreneurial awareness, conventional method and rigid index system should be abandoned, "one size fits fall' should not be engaged in and students' personality and original intention should be fully respected. Meanwhile incentive system of innovation and entrepreneurship education quantifies innovation achievements obtained by students who own patents and win awards. For those with outstanding evaluations, universities and enterprises can provide entrepreneurial supports in terms of funds, technical guidance and equipment etc.

\section{Teacher team for innovation and entrepreneurship education of fashion major}

The construction and allocation of teachers is vital to the successful implementation of innovation and entrepreneurship education. Teachers involved in the program are based on the characteristics of courses. ${ }^{6}$ At present, most teachers of entrepreneurial courses come from economics and business management majors or career guidance centers on campus. They are familiar with theoretical knowledge of entrepreneurship, but actually lack entrepreneurial experience, which is a problem and challenge for the effectively implementation of innovation and entrepreneurship education. Aiming at strengthening the construction of teacher team of innovation and entrepreneurship education, "enterprise-background" full-time teacher and part-time teachers from enterprises are two solid forces of faculty team. In particular, teaching team facilitates the access of teaching positions to people directly related to special field in fashion industry, successful entrepreneurs are included in teaching team, as well as well-known alumni, diversified experts, lawyers and government officials. All teachers' themselves resources will be gathered and the 
structure of teacher team will be optimized, so as a team, integrating knowledge and skills, academic and social needs, innovation and entrepreneurship, was jointly built. The ratio of teachers in interdisciplinary such as fashion, technology, business management and computers is rationally allocated. Policies and measurements will carry out to explore and train teachers with experience in innovation and entrepreneurship education, to select and train professional teachers with the potential for innovation and entrepreneurship, to provide teachers with entrepreneurial funding, to allow, encourage and support teacher's innovation and entrepreneurship, so that fashion teachers can truly understand and grasp theories and skills of innovation and entrepreneurship.

\section{Textbook of innovation and entrepreneurship education of fashion major}

"The supply chain of the apparel industry moves at an everincreasing pace. This pace is very difficult to keep up with in the educational system where textbooks are almost outdated by the time they reach the classroom". 7 The lagging development of innovation and entrepreneurship teaching materials in fashion is a common and worldwide issue, lacking of systematic, operable, targeted and authoritative textbooks. Due to the strong practicability of innovation and entrepreneurship education, the difficulty of teaching materials development has been increased. It recommends, base on innovation and entrepreneurship in each country, to fully embody individually national policies and regulations, to meet the needs of carrying out innovation and entrepreneurship education in fashion major.

\section{Results}

BIF teaching model is a design centered model, and has been executed for three semesters as a partial imitation for fashion students to experience innovation and entrepreneurship education using the framework proposed previously as foundation. This BIF project was under the guidance of one tutor and lasted for one month in a course. Some steps of two cases completed by students are shown in Figure 2 and Figure 3. BIF, namely Business+Internet+Fashion, integrates business, computer technology/internet and fashion design across disciplines, and implements fashion product development and commercial operation, as shown in Figure 4.

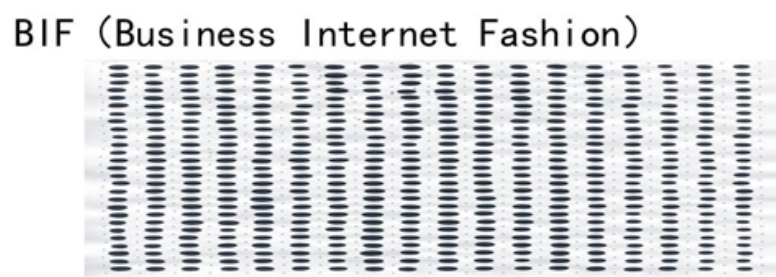

Team name:SIX

Member: Lai Chutao,Lu Shenyu,Huang Yanting,Feng Xinxin,Wen Zhiyi,Wu Zhixin

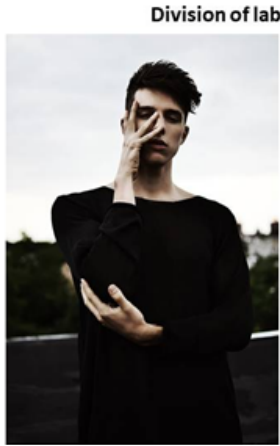

4.drawing (Wen Zhiyi)

5. Purchase(Huang Yanting, Lai Chutao)

6.Suppliers(Lai Chutao)

7.Make(Feng Xinxin, Lu Shenyu)

8.Record(Wu ZhiXin)
Prophase

Subject discussion

Determine the design theme

Theme:Combination

Objectives: A set of women's dress

Technology: Laser cutting

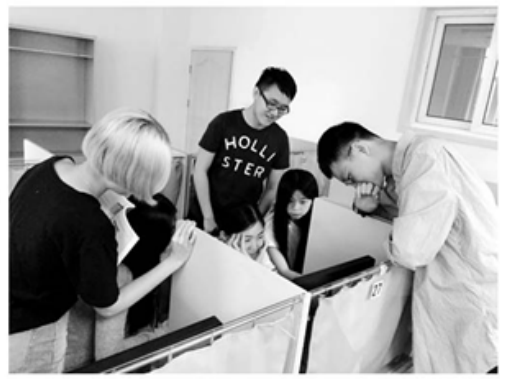

FABRIC

We look for the right fabric suppliers in Shenzhen's major fabric market.

We went to the east city fabric, Textile City, Da Tong Lok, and Hua Hui

(They are located in Luohu District, Shenzhen)

By Huang Yanting/Lai Chutao

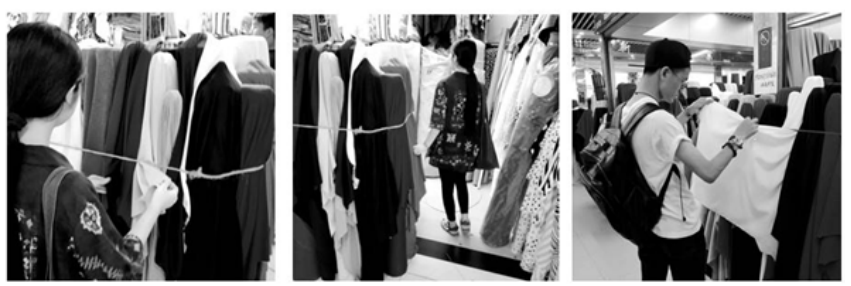

Please contact selected factories in Advance.

By Lai Chutao
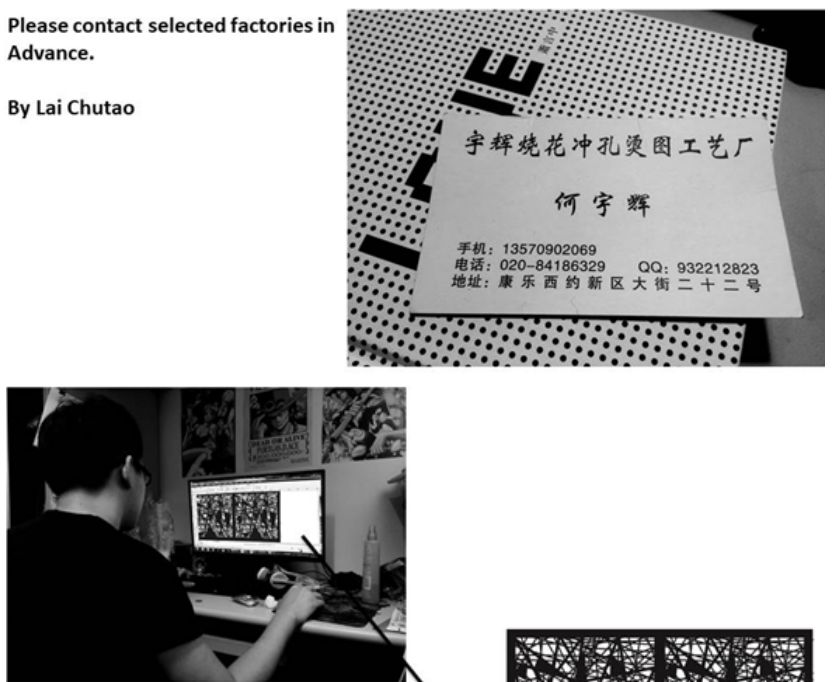

Drawing the pattern to be cut By Wen Zhiyi
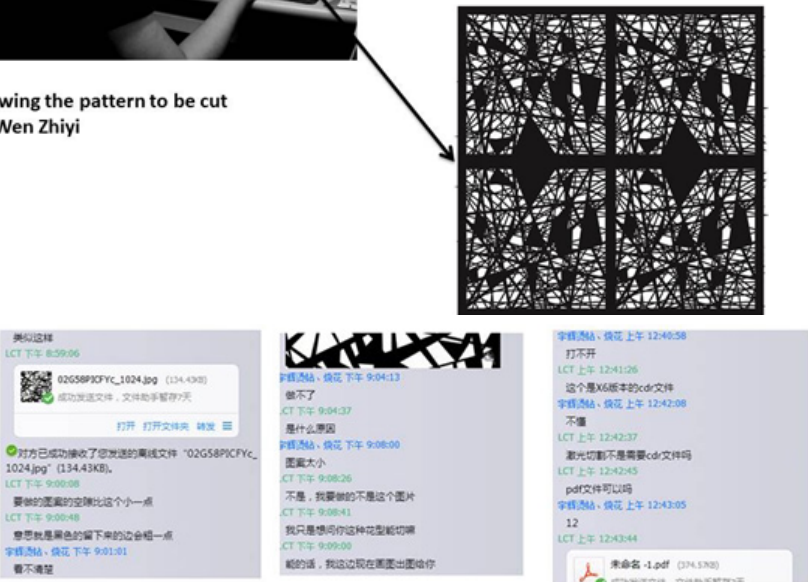

Problems occur during the process and how to solve problems By Lai Chutao 


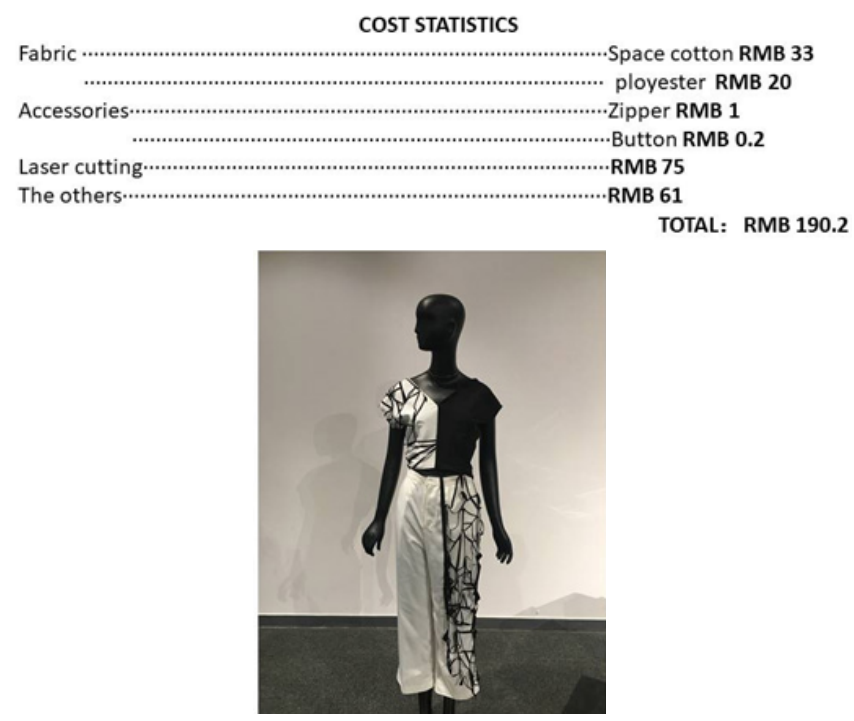

Figure 2 BIF case I.

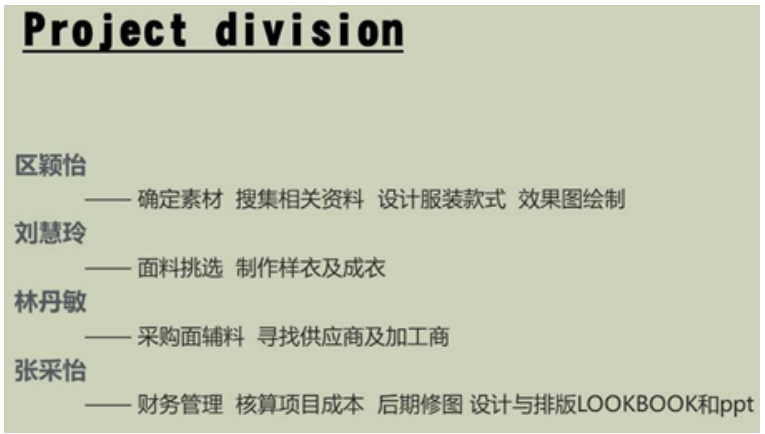

\section{Time budget}

\begin{tabular}{|c|c|c|}
\hline Time & Department & Work arrangement \\
\hline $\begin{array}{c}\text { Before } \\
12.08\end{array}$ & 全体 & $\begin{array}{l}\text { 找外景地点 确定模特 并拍摄LOOKBOOK外景部 } \\
\text { 分 后期修图 整理这次项目的过程与完整ppt } \\
\text { LOOKBOOK装订 }\end{array}$ \\
\hline $\begin{array}{c}\text { Before } \\
12.05\end{array}$ & 工艺部 & 制作成衣 \\
\hline \multirow{4}{*}{$\begin{array}{c}\text { Before } \\
12.03\end{array}$} & 设计部 & 样衣确认 协助工艺部 \\
\hline & 工艺部 & $\begin{array}{l}\text { 开始依据工艺单立裁打板 制作第一次样衣并集 } \\
\text { 体审核 修改或调整样衣 制作第二次样衣 集体 } \\
\text { 审核 }\end{array}$ \\
\hline & 采购部 & 样衣审核通过后开始采购面料辅料等所需材料 \\
\hline & 财务部 & 与面料加工商协调，确定加工时间用量及费用 \\
\hline
\end{tabular}

\section{Supplier}

\begin{tabular}{|c|c|c|}
\hline 永昌盛辅料行 & $\begin{array}{l}\text { 深圳市罗湖区东门中 } \\
\text { 路东大布抟辐科城四 } \\
\text { 楼 } 4033 \\
13714606627 \\
\end{array}$ & : \\
\hline 文隆布行 & $\begin{array}{l}\text { 深圳市罗湖区东门中 } \\
\text { 路大童乐三楼207 } \\
\text { 25859223 }\end{array}$ & \\
\hline 一万布业 & $\begin{array}{l}\text { 深圳市罗湖区东门中 } \\
\text { 路东大布料畜家城负 } \\
\text { 二楼B100-101 } \\
13510022400 \\
\end{array}$ & \\
\hline
\end{tabular}

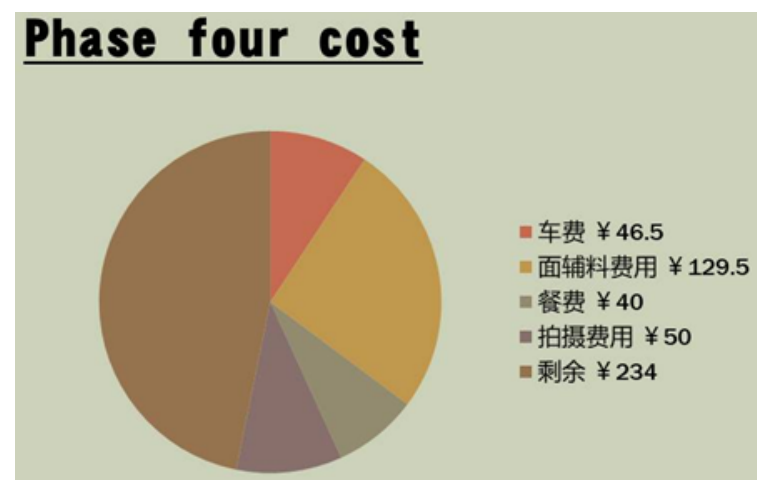

\section{Dress collocation}

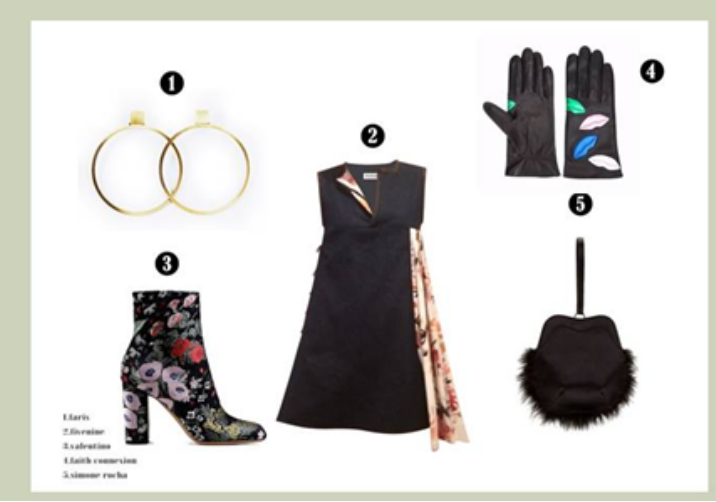

\section{Clothing display}

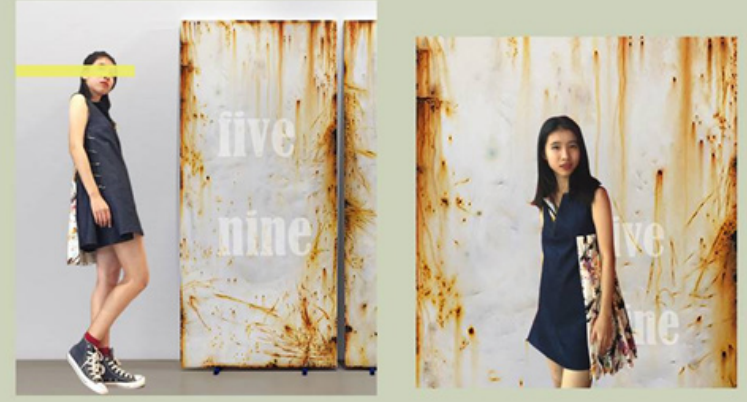

Figure 3 BIF case 2.

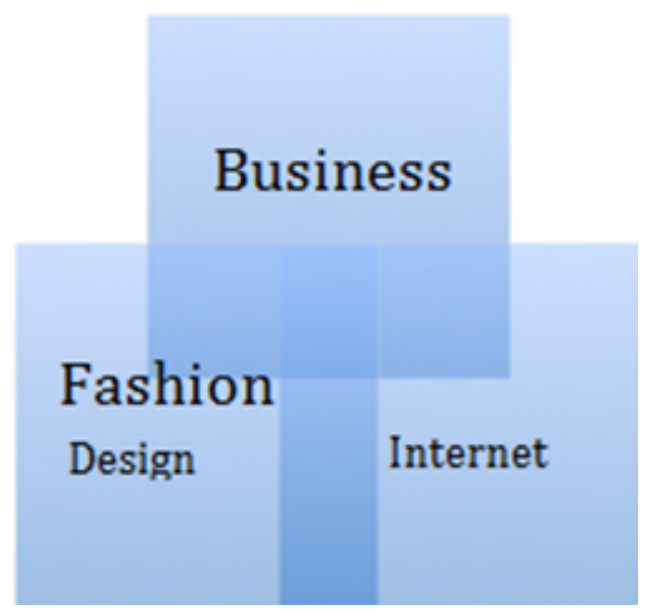

Figure 4 BIF teaching method of innovation and entrepreneurship in fashion major. 
Among them, business is responsible for looking for material suppliers and product manufacturers, inquiring and confirming prices, ensuring delivery time and quality, and other merchandising' processes and tasks. As for Internet, it was use as a tool to explore the latest fashion trends, search suppliers and manufacturers; the application of computer technology in fashion design can be either used as design tools or sources of design inspiration; online sales platform is build, such as online stores and micro-businesses, as shown in Figure 5. Design is based on market trends and demand analysis, materials collection and determination of design elements are one of processes, next step is drawing innovative product sketches, choosing colors and fabrics, and finally form a design scheme.

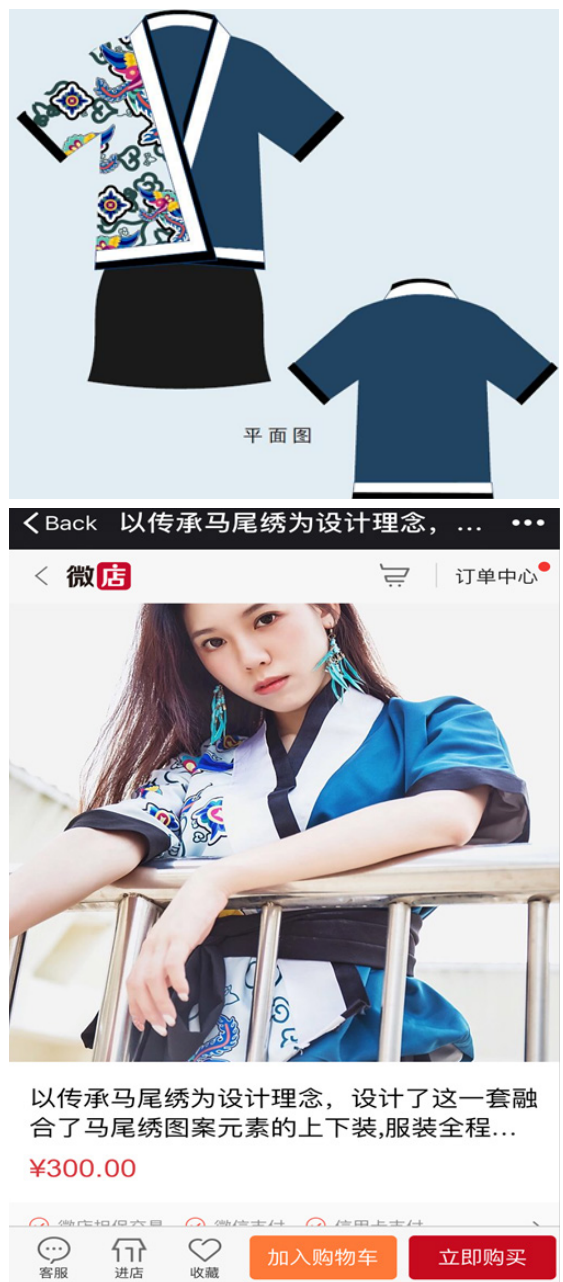

Figure 5 Design and online sales platform.

BIF is oriented by improving quality of innovation and entrepreneurship, emphasizes the training of innovative and entrepreneurial thinking and ability, with practice as priority. Through collective creativity, design process can simultaneously promote several creative ideas. When adopting BIF, students must complete building team, division of tasks, planning, target customer analysis, competitive product analysis, product demand analysis, product design, supplier search and negotiation, merchandising, production, product shooting, look book, establishment of business model, cost control, expected profitability, progress control, quality control, etc.

Meanwhile, BIF highlights the teaching concept of "studentoriented, teacher-led", is characterized by student practice and teacher- student interaction instead of instructor focused. During project-based teaching of BIF, teachers create a positive and dependent learning environment; team members interactively discuss innovative design topics by sharing individual thoughts and experiences, as well as brainstorm, and develop abilities of communication and expression; students' problem-solving abilities are enhanced through task division and cooperation; the team finally jointly achieves design goals.

The relationship between knowledge transfer, skill training and innovation and entrepreneurship is appropriately handled during teaching. BIF model emphasizes the cultivation of ability of innovation and entrepreneurship under changing environments, e.g. ability of acquiring and organizing interdisciplinary information, self-study ability in diversified fields, comprehensive professional ability, awareness of cost and time, flexibility and tolerance, and other abilities in modern workplace. BIF teaching method also emphasizes teamwork, each team member has his or her own skills and resources that he or she is good at. In particular, the fashion design students in each group played important roles as technical designers, pattern makers, and sample makers. ${ }^{8}$ And only through cooperation in various fields of design, technology and market, can they be professionally complementary, trust each other and integrate resources in a scientific and orderly organization, and achieve the set goals through the joint efforts of team members. BIF teaching model is especially suitable for innovation and entrepreneurship education in fashion major.

In BIF model, conventional teaching methods such as heuristic, case, discussion, participation and interaction etc., are adopted actively, state-of-art teaching methods including flipped classroom, MOOC and micro-classes are highly recommended. Modern information technology such as computer network technology, mobile app and VR are applied to reform teaching methods. All pedagogical approaches aim at guiding students to inspire innovative and entrepreneurial ideas, and fully mobilize students' enthusiasm, initiative and creativity to participate in innovation and entrepreneurship.

Positive outcomes from BIF teaching model, students tend to learn more effectively, utilize a real-world situation working with suppliers and manufactures. Such project prepares students to think and act like entrepreneurs inside the classroom..$^{9-13}$

\section{Conclusion}

By exploring entrepreneurship in the fashion design field, a scientific and complete education system of innovation and entrepreneurship in fashion major is proposed, thus innovation and entrepreneurship education is integrated into the incumbent education system. Talent training of innovation and entrepreneurship in fashion major is improved by an imitation teaching model BIF, which testifies the framework in cultivating high-quality compound talents with innovative thinking and entrepreneurial capability. The framework and the verified BIF methods equip students with both fashion skills and innovation and entrepreneurship competency, and create competitive advantage in ever-changing fashion industry. This pragmatic way of education in fashion major can be further leveraged by extension of marketing involvement such as customer and channels to mirror the wider fashion industry and contribute to diversifying fashion education.

\section{Acknowledgments}

None. 


\section{Funding}

The research project was sponsored by Educational Science Research Institute of Shenzhen. (No. ybzz17017)

\section{Conflicts of interest}

Author declares there is no conflict of interest in publishing the article.

\section{References}

1. Ketchen DJ, Ireland RD, Webb JW. Toward a research agenda for the informal economy: a survey of the strategic entrepreneurship journal's editorial board. Strategic Entrepreneurship Journal. 2014;8(1):95-100.

2. Mahajan S. Economics of South African township: Special focus on diepsloot. Washington, DC: The World Bank; 2014.

3. Clara Eloise Fernandes. Fashion design entrepreneurship: skills and solutions to create a fashion business. J Textile Sci \& Fashion Tech 2019:3(1).

4. Thea JT. When clothing designers become business people: a design centred training methodology for empowerment incubation. International Journal of Fashion Design, Technology and Education. 2018;11(3):299309.
5. Asper P. Using design for upgrading in the fashion industry. Journal of Economic Geography. 2009:10(2):189-207.

6. Kirzner IM. Competition and entrepreneurship. Chicago: University of Chicago Press; 1973.

7. Laurie MA, Lance C. Globalization of apparel technology in university apparel programs. J Textile Sci \& Fashion Tech. 2018;1(2).

8. Chae May. An innovative teaching approach to product development: creating tennis wear for female baby boomers. Fash Text. 2017:4(13).

9. https://www.babson.edu/

10. http://www.gsb.stanford.edu/

11. McKelvey K, Munslow J. Fashion design: Process, innovation and practice. London: Wiley; 2011.

12. Sousa G, Simoes I, Maldonado P. Entrepreneurship education for fashion design. In: Karwowski W, Ahram T, Nazir S, editors. Advances in human factors in training, education, and learning sciences. Advances in Intelligent Systems and Computing, Springer; 2019:284-291.

13. Kurz Elisa. Analysis on fashion design entrepreneurship: Challenges and supporting models. 2010 